\title{
Quality Of Arguments Used In The First-Round Presidential Debate: Critical Pragmatics And Stephen Toulmin's Perspective
}

\author{
Yuliana Setyaningsih, R. Kunjana Rahardi
}

\begin{abstract}
It is important for politicians to have a good argumentative skill. For state leaders, the ability to think logically, to use rhetoric, and to argue systematically, scientifically, sharply, and eloquently is very crucial. The year 2019 is the political year for Indonesia. Political campaigns leading to the presidential and the legislative election, both in national and regional levels, will happen in 2019. The focus of this research is to investigate the depth and breadth of the arguments stated by the presidential candidates and how those arguments are presented. The research substantial data source is in the form of speech transcript of the recorded video of the firstround presidential debate by two pairs of president and vicepresident candidates. The research data were the debate arguments found in the video transcript and the contexts surrounding them. The data gathering method used observation by employing recording and note-taking techniques. After the data were gathered, they were selected and classified based on their types for further analysis. The analysis method was distributional method and content analysis. Both data analysis methods were applied to yield significant results of the study. The results showed that there are simple patterns of argument containing claim, subclaim, data, and warrant. The orders of elements of arguments might be varied. The research results also showed that there were various pragmatic meanings found in the arguments used by the president and vice-president candidates. The results of the study which was analyzed using the critical pragmatic perspective reflect how far the candidates were concerned with the marginalized, the underprivileged, and the subjugated people.
\end{abstract}

Index Terms: Critical pragmatics, political argumentation, presidential debate

\section{INTRODUCTION}

The linguistic and non-linguistic studies of speeches delivered by political leaders in advanced countries have been widely conducted (1). This study is important because studies on the substance and language of the speeches will be beneficial for educational and research purposes. Such academic studies should be separated from political dimensions because the study is purely intended for academic purposes, as in education and research (2).

In Indonesia, a study on the discourses has not been widely conducted. As a matter a fact, political views put forth by the politicians contained in the discourses are very beneficial for learners and scientists. For this purpose, this

Revised Manuscript Received on April 19, 2019.

Yuliana Setyaningsih, Master Program of Indonesian Language and Literature Education, Sanata Dharma University, Yogyakarta, Indonesia

R. Kunjana Rahardi, Master Program of Indonesian Language and Literature Education, Sanata Dharma University, Yogyakarta, Indonesia article is written so that it can be read by a wider audience. Like the writers in the advanced countries, this article is free from political bias and alignments with the politicians featured in the discourses being analyzed .

Specifically, this article only focuses on the spoken argumentative discourses presented by the presidential candidates in the debate in 2019. Due to some limitations, the argumentative discourses used as the source of research substantive data are limited to the first-round of the presidential debate. The debate's argumentative discourse in other rounds are treated as being outside of the scope of this article writing.

The purpose of the research is to find out the extent to which these Toulmin's model of argument (3) is applied by the presidential candidates to build arguments in the first round of the presidential debate. Furthermore, this research is also intended to determine the extent to which the presidential candidates and their running mates take sides with the marginalized people in the broadest sense through the first round of presidential debate.

\section{LITERATURE REVIEW}

Theoretically, two main theories are used in this research. The first theory is the pragmatics in relation with contexts. The second theory is the model of argument proposed by Toulmin (4). The two theories are used as the frame of reference and as the analytical tool to carry out this research. It needs to be clarified that pragmatics is the study of language with the objects in question being outside the language (5). Experts argue that pragmatics is the study of speaker's intention. The instruments used to conduct a pragmatic analysis is context, especially situational contexts. Context is understood as the background knowledge shared by the interlocutors (6), (7).

Understanding of the right and correct contexts will allow one to draw meaning from the right context. On the contrary, insufficient understanding of the substance of context results in imperfect interpretation of the utterance. Even worse, it can stray from its intended meaning. Therefore, the argumentative discourses spoken by the presidential candidates in the debate must be interpreted correctly and profoundly.

Published By: 
Critical pragmatics is slightly different from pragmatics in general (8), (9). Furthermore, it should be conveyed that in addition to being the most recent branch of linguistics, pragmatics is understood as the study of external linguistic units. Parker asserts that 'pragmatics is the study of how language is used to communicate. Pragmatics is distinct from grammar, which is the study of internal structure of language.'(10) What is meant by the study of the external linguistic units is that a language must be interpreted based on the non-linguistic factors outside the language (11).

Therefore, the external linguistic factors are also called extra-linguistic factors. The meaning inferred from the pragmatics study is the contextual meaning or the pragmatic meaning, or commonly referred to as intent. Thus, intent is actually the pragmatic meaning, instead of semantic or linguistic meaning (12). What determines the pragmatic meaning or intent, commonly referred to as speaker's meaning, is contexts, especially the situational contexts (13). In different situation, two identical statements can result in two different meanings. Therefore, pragmatic meaning or intent is always contextual and situational. Different situations result in different speaker's intent. In a nutshell, the linguistic intention is the main focus of pragmatic study (14).

In the studies, pragmatics cannot be separated from the from context, especially the situational contexts. To interpret the pragmatic meaning or intent, the situational context is absolute and binding. Therefore, pragmatics is a contextbound study, and the context refers to the situational context as discussed earlier (15). Assumptions as the main substance of the pragmatic context are not always revealed clearlt by the experts. The assumptions are interpreted in a relatively different manner by different pragmaticists. Several other prominent pragmatics theoriests do not place assumptions as the main contextual substance in the pragmatic study. Moreover, if pragmatics is interpreted as the study of speaker's intent, the critical pragmatics focuses on the dimensions of alignments with the marginalized parties and the marginalizing party (6).

The review of the tracing of contexts in the pragmatic study in this research begins with the description proposed by Yan Huang, a Chinese pragmatist, who firmly believes that pragmatic contexts can be interpreted by referring to the things related to the dynamic setting and environment in which the linguistic entity is used systematically. Huang states that 'context can be seen as composed of three different sources - a view known as the 'geographic' division of context. In the first place, there is the physical context, which refers to the physical setting of the utterance. The second type is the linguistic context, which refers to the surrounding utterances in the same discourse. Thirdly and finally, we have the general knowledge context.' (16)

In Stalnaker's view, the terms refer to 'common ground' or 'shared background knowledge'. Stalnaker's view that a pragmatic context is understood as the 'common ground' is explained in detail by Clark, who further divides it into two categories, namely communal common ground, and personal common ground. Therefore, from the previous views, the nature of the pragmatic context is not the physical context and linguistic context, but the general knowledge context, which is further interpreted as the set of background assumptions shared by the the speaker and the hearer (17).

The theoretical review of the second theory starts by presenting the view from a well-known anthropologist, Edward T. Hall, who asserts in relation to context that 'information taken out of context is meaningless and cannot reliably intepreted'. Hall suggests that in an utterance, three entities must always exist together, namely information, context, and meaning. When the three entities cannot be separated from one another, each has a very dynamic relationship. It is asserted that any information will never have a non-conceptual meaning, especially pragmatic meaning, unless the identity of the context is clear. Thus, context will appear only when the three requirements are met, namely the setting, which includes the dimensions of time, place, and the surrounding material elements, the activities, which involve either verbal or non-verbal actions, the relationship between the speaker and the hearer which is influenced by factors such as gender, age, status, role, achievement, prestige, familial relationship, professional relationship, education, etc. (18)

The next theoretical review of the context is stated by Keith Allan. This expert firmly distinguishes context into three categories, namely the physical context or setting of the utterance, the word spoken in an utterance, and the textual environment. For the purpose of this short article, Allan's ideas on the second category of contexts are in line and relevant, namely "the world spoken of" which can be interpreted as "the subject matter being discussed." (19) More specifically, Allan stated that the nature of contexts was actually not just "the world spoken of" but "the real world spoken of". Thus, personal and communal assumptions are not abstract assumptions, which are still vaguely understood by the speaker and the hearer, but they must be concrete assumptions as suggested by Allan (20).

Regarding this, Ron Scollon and Wong Scollon distinguish the fundamental difference between 'sentence meaning' and 'speaker's meaning. The first concept is understood based on the 'knowledge of grammar', while the second concept depends on the 'knowledge of context'. In a similar vein, they assert that 'Understanding both sentence meaning and the speaker's meaning requires two kinds of knowledge. Sentence meaning depends on knowledge of grammar, speaker's meaning depends on knowledge of context.' Further, Scollon \& Scollon assert that knowledge of context requires two kinds of shared knowledge, namely shared knowledge of actions and situations, and shared knowledge of relationship and identities (21).

Furthermore, the second theory used as the framework of the research was the theory of argumentation (22). There are a number of theories to be applied in researching argumentative discourses such as debates. However, in this research, the theory of argumentation in Stephen Toulmin's perspective was used. In his perspective, he asserts that an argumentation consists of a number of elements which build the structure of an argument. The first element is claim or positional statement. The element of positional statement is 
absolutely needed in an argument. Without such element, a discourse cannot be considered a good argument. The positional statement is not enough without being supported by elements of data. Elements of support are very crucial in Toulmin's argumentation structure because data warrants objectivity.

Furthermore, the second theory used as a framework in this study is the theory of argumentation. There are a number of argumentation theories to analyze argumentative discourses such as debates. However, this research applied the argumentation proposed by Toulmin. In his perspective, it is described that an argument contains several parts building the structure of argument (23). The first part is claim or the controlling idea. The positional statement must be absolutely present in an argument. Without this element, a discourse cannot be said as an argument. The existence of a positional statement is not enough to build a good argument.

The positional statement must be supported by valid data. The elements of data supports is dominant in Toulmin's argumentation structure because data serves as the warrant of subjectivity. Without being based on the clear and concrete data and fact, the argument being built is very weak (24). Thus, the positional statement and support are two crucial and basic elements of building a good and strong argument. Data supports the formulation of the positional statement. In addition, data also supports the correct positional statement. However, a strong positional statement and sufficient data or facts cannot adequately be used to claim that the argument is strong and solid. The third element, warrant or strong beliefs, cannot be neglected. Warrant is essentially an element that warrants all the other elements, namely positional statement and supporting data, as valid. Thus, warrant are important because they provide underlying reasons linking the claim (positional statement) and the support (data, facts, etc.) (24), (23)

The three elements previously mentioned are the major parts of an argument. The parameter of strong argument can be seen from the existence of those three elements. If all three element are missing, the argument is not of a good quality.

Besides the three major parts presented earlier, a good and valid argument must be equipped with three additional elements, namely backing, rebuttal, and modal qualifier. Both theories are used as the frame of reference and the analytical tool to see the depth and wholeness of the structure of arguments being presented.

\section{RESEARCH METHODOLOGY}

The research on the argumentative discourses of the presidential candidates and their running mates in the firstround debate is descriptive qualitative. The substantive data sources of this research is the recorded video of the firstround presidential debate dated January 17, 2019. The recorded video consists of six segments discussing a range of topics such as Law, Human Rights, Corruption, and Terrorism.

From the substantive data source, a research data is gathered to write this article. The research data is the excerpts of utterances containing argumentative elements proposed by Toulmin. The data was gathered using the observation method by employing recording and note-taking techniques as the basic and advanced techniques (25). The research data will be further analyzed using Toulmin's theory of argument and the critical pragmatic theory and contexts.

Therefore, the analysis method to be used to analyse the research data was the the distributional and contextual analysis methods (26). The distributional analysis method was applied to obtain the idea of argumentative structure and elements, while the contextual analysis was used to interpret data from the perspective of critical pragmatics.

\section{RESULT AND FINDINGS}

The data being analysed covers the topics of the firstround presidential debate, namely, Law, Human Rights, Corruption, and Terrorism. The data shown in the following excerpt is not the raw data of the research, but it is a readymade data to be subject to analystical methods and techniques discussed earlier. The ready-made research data was analysed and interpreted by implementing theories used as the theoretical framework and analytical tool (24). The following excerpt illustrates the point.

\section{Excerpt 1}

M: "Pemberantasan terhadap terorisme sering kali berbenturan dengan isu hak asasi manusia. Bagaimana strategi Anda agar pemberantasan terorisme bisa benarbenar dijalankan tanpa ada persepsi dari masyarakat tentang terjadinya pelanggaran HAM. ..

\section{Translation:}

M: The efforts to eradicate terrorism often clashes with human rights issues. What is your strategy so that terrorism can be eradicated without leaving public perception that human rights are violated?

P1: Terorisme adalah merupakan kejahatan. Oleh karena itu, terorisme harus diberantas sampai ke akar-akarnya. Ulama Indonesia telah mengeluarkan fatwah bahwa terorisme bukan jihad. Oleh karena itu, haram dilakukan, bahkan terorisme dianggap melakukan kerusakan. Ihzad dalam Alqur'an dinyatakan bahwa orang yang melakukan kerusakan di bumi harus dihukum dengan keras, dengan berat. Oleh karena itu, upaya-upaya menanggulangi terorisme harus dilakukan dengan dua cara mensinergikan antara pencegahan dan penindakan. Ke depan kami lebih mengutamakan pencegahan melalui kontra radikalisme untuk menghilangkan atau menekan faham-faham radikal dan intoleran dan melalui deradikalisasi untuk mengembalikan mereka yang sudah terpapar. Untuk itu, di dalam melakukan tindakan, kami juga lebih melakukan pendekatan yang humanis, yang manusia, dengan tidak melanggar HAM atau hak asasi manusia. Untuk itu, dalam menanggulangi terorisme di masa yang akan datang, kami akan mengajak ormas-ormas (organisasi masyarakat) khususnya organisasi keagamaan.

\section{Translation:}

$\mathrm{P} 1$ : Terrorism is a crime. Therefore, terrorism must be

Published By:

Blue Eyes Intelligence Engineering

\& Sciences Publication 
eradicated to its roots. Indonesian ulemas have issued an edict that terrorism is not jihad (holy war). Thus, it is forbidden, because terrorism is considered as causing harm to others. The verse in the Holy Qur'an states that any party who causes damage to the earth must be pusnished severely and heavily. Therefore, the efforts to eradicate terrorism must synergize two different ways, namely prevention and prosecution. In the future, we will prioritize prevetion through counter-radicalism to eliminate or suppress radical and intolerant ideologies and through de-radicalization to rehabilitate those who have been exposed to radicalism. For this measure, to execute the action, we prefer to use a humanistic approach, in order not to violate any human rights. To combat terrorism in the future, the government calls for the community organizations, especially religious organizations, to work hand in hand.

P2: Saya melihat bahwa aparat harus diberi ilmu

\section{Translation:}

P2: I see that the officials must be given the knowledge of Human Rights.

The argumentative construction in the exceprt is relatively complete. It can be seen that claim, subclaim, data, and warrant are present in the argument. There are three claims identified from the excerpt, namely 'Terrorism is a crime,' 'Thus, the efforts to eradicate terrorism must synergize two different ways, namely prevention and prosecution,' and 'I see that the officials must be given the knowledge of Human Rights.' The argument constructed by three inter-connecting claims shows that the speaker's argument is very strong. The claim is even stronger when it is supported by the sub-claims which elaborate the same topic.

There are 2 subclaims in the above excerpt. The data element as the supports of the claim and subclaim can be shown in the argumentation even though the quantity is still limited. The link between data and claim appears in the warrant statement 'The verse in the Holy Qur'an states that any party who causes damage to the earth must be pusnished severely and heavily.'

The substance of argument in the previous excerpt is interesting to observe from the critical pragmatic perspective. To interpret the utterances spoken by the statesmen above, we cannot neglect the context of the utterances, which manifest in the reality of the utterances. The critical pragmatic perspective that links the context and takes sides with the human dimensions, such as 'humanistic approach', 'not violate human rights,' 'counter-radicalism' and 'de-radicalism' can be seen in the excerpt. Thus, the data contain dimensions of critical pragmatics (27).

Attention and alignment with the socially, politically, economically disadvantaged parties can be identified from the excerpt. Pragmatically, this refers to the essence of solidarity, namely the solidarity for whose cause they fight for. The aspiring leaders who understand the true meaning of solidarity are true leaders, because essentially being leaders mean striving to save the marginalized and underprivileged community to guarantee people's social welfare as a result of good leadership. pengetahuan mengenai HAM.

Further, the following chart illustrates the relationship between elements in the argumentative construction.

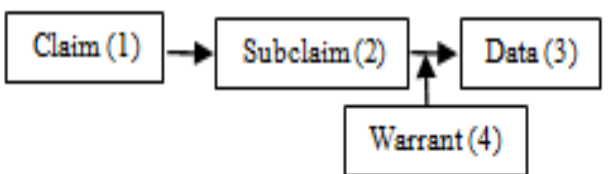

Chart la. The structure of argument with C-Sc-D-W elements

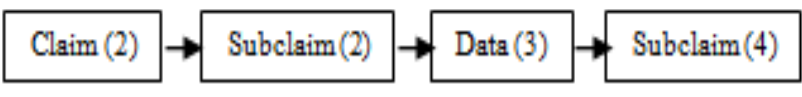

Chart $\mathrm{lb}$. The structure of argument with C-Sc-D-Sc elements

\section{Excerpt 2}

Mt: Jadi waktu saya masih muda, saya spesialisasinya adalah di bidang antiteror. Saya yang bentuk bersama dengan Pak LP, pasukan antiteror yang pertama. Jadi, saya mengerti, saya paham, masalahnya adalah karena pengalaman saya itu, saya mengetahui bahwa seringkali terorisme ini adalah dikirim dari negera lain dan sering juga dibuat nyamar seolah terorisme itu dari islam padahal itu sebetulnya di bi, di, yah dia itu bukan dikendalikan oleh orang yang mungkin juga bukan orang islam. Mungkin juga orang asing ataupun bekerja untuk orang asing. Saya mengerti, benar-benar. Jadi, bahwa stigmatisasi bahwa seolah-olah itu bahwa radikalisme selalu dicap di orang islam, saya menolak itu. Saya setuju deradikalisasi, saya dukung usaha-usaha kemanusiaan.

\section{Translation:}

Mt: When I was young, I specialized myself in antiterrorism. I collaborated with Mr. LP to form the first anti-terror force. So, I understand, I understand the problem from my experience. I know that sometimes terrorists are sent from other countries and they often disguise themselves to leave an impression that terrorism is identical with Islam, which is well...it is actually controlled by non-muslims. They may be foreigners or they may work for the foreign people. I understand really. So, the stigma they want to make is that as if radicalism is always associated with Islam. I disagree with that. I agree with de-radicalisation. I support humanistic efforts.)

The structure of the above argumentative text from Excerpt 2 shows that the argumentative elements contained in the text consist of the claim and the support. Looked even closely, the presentation of argument in Excerpt 2 starts with the presentation of data, and ends with claim and even more supported by subclaim from the first sentence through the third sentence. The three data support the claim, which reads 'So, the stigma they want to make is that as if radicalism is always associated with Islam. I disagree with that.'

The claim is confirmed by the subclaim that says 'I agree 
with de-radicalisation. I support humanistic efforts.' The structure of argument consists of the support and the claim as a simple pattern of argument according to Toulmin. Without the warrant element in the excerpt, it can be said that the argument lacks astuteness (3).

In the excerpt of the data above, the critical pragmatic perspective is quite obvious, as in the struggle of the presidential candidate to provide social welfare for the people that he will presumably lead if elected. The candidate's statement that he will take side with the humanity in leading the country, supporting de-radicalism in combating terrorism, as such, is intended pragmatically to assert that none of the citizen will lose his/her life due to the lack of humanity. Likewise, the candidate's statement that he will support deradicalism to eradicate terrorism signals his intention to ennoble humanity (28).

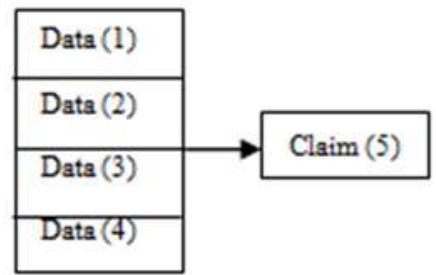

\section{Chart 2. The structure of argument with D-D-D-D-C elements}

\section{Excerpt 3:}

P: Kita tahu korupsi adalah kejahatan yang luar biasa. Bahkan pak $\mathrm{P}$ pernah mengatakan bahwa korupsi di Indonesia sudah stadium empat. Meskipun ini saya gak setuju, saya gak setuju. Tapi menurut ICW, ini menurut ICW partai yang bapak pimpin termasuk yang paling banyak mencalonkan mantan koruptor atau mantan napi korupsi yang saya tahu caleg itu yang tanda tangan adalah ketua umumnya. Berarti Pak $\mathrm{P}$ yang tanda tangan, bagaimana bapak menjelaskan mengenai ini?

\section{Translation:}

P: We know that corruption is an extraordinary crime. Mr. P mentioned that corruption in Indonesia is in the last stadium. I do not entirely agree. I disagree. But according to Indonesian Corruption Watch, well..this is according to $\mathrm{ICW}$, the party that you lead is included in the party which gives tickets to ex-convicts with corruption charges to run for legislative election. To run for the election, they would require the party leader's approval signature. It means that you gave your approval signature. Can you explain this?

The excerpt of the argumentative text above contains the major parts of argument according to Toulmin. Despite its short paragraph structure, the three major parts are present. The positional statement (claim) in the beginning of the text says 'We know that corruption is an extraordinary crime.' The positional statement (the claim) is not left alone, but supported by two data presented consecutively. This makes the positional statement stronger (24). The speaker still supports the positional statement with the warrant, which says 'But according to Indonesian Corruption Watch, well this is according to ICW, the party that you lead is included in the party which gives tickets to ex-convicts with corruption charges to run for legislative election. To run for the election, they would require the party leader's approval signature.'

The two supporting data solidifies the claim because of the warrant. The speaker feels that he has not finished elaborating his arguments in the argument constructed with three major parts, so that at the end of the text, he adds one more element, namely backing, which says 'It means that you gave your approval signature. Can you explain this?' Therefore, it can be confirmed that the excerpt of the argumentative text above is considered excellent seen from the perspective of argument construction.

Pragmatically, the above text has an extremely strong degree of transparency. The claim, the support, and the warrant are presented clearly and prove that they have a high degree of directness. The high degree of directness is actually not ideal to convey certain intentions which contain facts. However, seen from the speaker's intention, the presidential candidate tries to convince that the leader of the country must be a person with good reputation. His supporters must also be clean, without criminal records, corruption allegations, etc. In other words, the presidential candidates must strive for the best interest of their country and the people. Thus, the country must be managed cleanly and honestly by well-reputed people, instead of by exconvicts of corruption charges (29).

Furthermore, the following diagram illustrates the relationship between elements in the argument construction of Data 3.

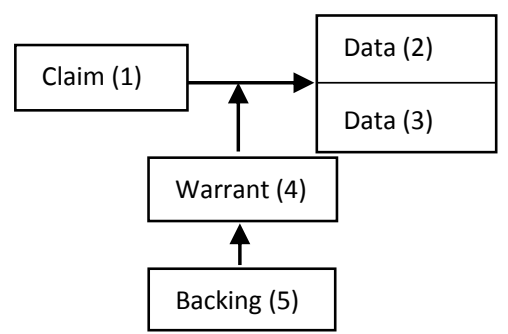

Chart 3. The structure of argument with C-D-D-W-B elements

\section{Excerpt 4:}

Mt: Baik, itu mungkin ICW. Tapi saya sendiri belum dapet itu, laporan itu. Yaa dan bener-bener itu saya kira sangat subjektif. Ya saya tidak, saya tidak setuju itu. Saya seleksi caleg-caleg tersebut, kalau ada bukti juga silakan laporkan juga kepada kami. Dan begini Pak, begini Pak begini, ada juga kadang-kadang ya tuduhan-tuduhan korupsi yang korupsinya itu yaa.. menerima THR seluruh DPRDnya, semuanya lintas partai Pak. Kalau sekarang kita cek di kejaksaan boleh kita bandingkan berapa orang yang sekarang sudah menunggu masuk KPK ataupun sudah ada di dalam penjara. Kita bisa cek, saya kira janganlah kita apa saling menuduh soal partai kita masing-masing ya. Saya jamin partai $G$ akan melawan korupsi sampai ke akarakarnya. Kalau ada anggota $\mathrm{G}$ yang korupsi, saya yang akan masukin ke penjara sendiri, cukup, pokoknya kita antikorupsi. 


\section{Translation:}

Mt: Fine. Maybe it was ICW. But I haven't received the report. Yes, I really think that is very subjective. Yes...I don't agree. I don't agree with that. I selected the legislative see, sir. Some corruption allegatiosn are directed to us, which actually...well...the recipients of the holiday benefits are all the members of the House of Representatives, everyone from many different parties. If we check in the attorney office we can compare how many people waiting in line to get to the Commision of Corruption Eradication or KPK and how many people already in jail. We can check. I think we should not turn against each other's party. I guarantee that the $\mathrm{G}$ party will fight corruption to its roots. Should a G party member commits corruption, I will send him myself to prison. Enough, the bottom line is, we are against corruption.

Compared to the excerpt 3 , the contrsuction of argument in excerpt 4 is less sharp. From the number of utterances, the text is longer and more elaborative than excerpt 3 . However, the text above only contains two main components, namely the claim and the support. The warrant element cannot be found in the text, but the claim is elaborated into several subclaim. There are four subclaims in the above excerpt. However, the subclaims cannot replace the warrant which is necessary to link the claim and the support presented by the speaker.

From the pragmatic dimension, the utterance in the above excerpt contains a high degree of transparency. However, the transparent intention does not refer to the real data. Alignment to the marginalized people is quite visible (30). The structure of arguments described above can be seen in the following scheme.

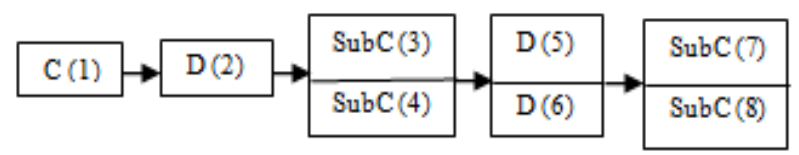

Chart 4. The structure of argument with C-D-Sc-Sc-D-D-Sc-Sc elements

\section{Excerpt 5:}

P: Mohon maaf Pak P, jadi yang saya maksud tadi adalah mantan koruptor atau mantan napi korupsi yang bapak calonkan sebagai caleg itu ada. ICW memberikan data itu jelas sekali, ada enam yang bapak calonkan dan yang tanda tangan dalam pencalegan itu adalah ketua umumnya dan sekjen. Artinya bapak tanda tangan. Jadi, jadi mohon maaf Pak P saya tidak menuduh partai bapak korupsi, ndak bukan. Ini mantan koruptor, mantan napi korupsi, yang sudah dihukum.

\section{Translation:}

P: Excuse me, Sir. So, did you mean that there are excorruptors or ex-convicts among your legislative candidates? ICW released the data clearly and publicly that there are six legislative candidates who obtain approval signatures to run for legislative election from the party leader and the general secretary. It means that you signed. So, I beg your pardon, Sir. I did not accuse your party for candidates, and if you find proofs, please let us know. You

corruption. No, do not misunderstand. I was referring to the former graft convicts, who were charged and convicted.

The argumentative text in Excerpt 5 has a structure of argument whose degree of astuteness is low according to Toulmin's Model of Argument. It was said so because the structure of argument in the data has two elements, the claim and the support (4). The claim in the text says: 'Excuse me, Sir. So, did you mean that there are ex-corruptors or exconvicts among your legislative candidates?' The claim is supported by two data consecutively, namely 'ICW released the data clearly and publicly that there are six legislative candidates who obtain approval signatures to run for legislative election from the party leader and the general secretary,' and 'It means that you signed.' Furthermore, the speaker gives two subclaims consecutively, saying 'So, I beg your pardon, Sir. I did not accuse your party for corruption. No, do not misunderstand,' and 'I was referring to the former graft convicts, who were charged and convicted.'

Pragmatically, the speaker conveys his intention in a high degree of directness, by presenting the fact clearly and transparently, when he mentions: 'ICW released the data clearly and publicly that there are six legislative candidates who obtain approval signatures to run for legislative election'; 'the authority who granted approval for legislative candidacy was the party leader and the general secretary'; I was referring to the former graft convicts, who were charged and convicted.' The high degree of directness, as shown in the above examples, is actually good in terms of the quality of the argument. However, pragmatically speaking, the interpersonal rhetoric must pay attention to the maxims of communication and the principles of pragmatics (13). In other words, such utterances do not clearly show the dimensions of pragmatics and critical pragmatics.

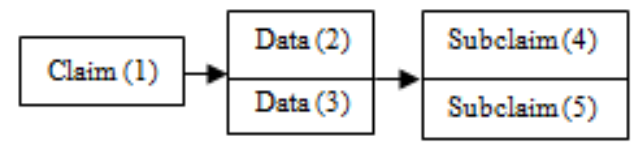

Chart 5. The structure of argument with C-D-D-Sc-Sc elements

\section{Excerpt 6:}

Mt: Jadi, mantan korupsi. Saya kira kita pelajari dan begini ini kan demokrasi Pak. Kita umumkan saja ke rakyat kalau rakyat gak mau milih ya gak akan dipilih, kan begitu. Yang jelas Pak kalau kasus itu sudah melalui proses, dia sudah dihukum atau dan kalau memang hukum mengizinkan kalau dia dianggap masih bisa, dan rakyat menghendaki dia, karena dia memiliki kelebihan-kelebihan lain, mungkin korupsinya ya gak seberapa, mungkin dia kena, mungkin dia.. ee begini kalau curi ayam bener itu salah tapi kalau merugikan rakyat triliunan itu saya kira yang harus kita habisken di Indonesia ini.

\section{Translation:}

Mt: So, former corruption convicts. I think we learn this and this is democracy, Sir. We will announce to the people 
that the people who do not want to vote for them, so be it. They should not give them votes to the former corruption convicts. What's important, Sir, is that the corruption case has been through the legal process. The convicts have served their time or when the law permits them to run for legislative election, it means that they are seen as capable and the people want them because of their other strengths, maybe the amount of money they corrupted was not much, maybe they got eh....maybe they....well, let's see if the petty criminals, you know, it's true that they are wrong for stealing chickens, but as long as they corrupted billions of money from the people, let's annihilate them from Indonesia.

The degree of astuteness of the argument is determined by the elements of the argument, such as the claim, the support, and the warrant. The application of those three elements to build a strong and astute argument must be supported with the sufficient data, both quantitatively and qualitatively (31). In the argumentative text in Excerpt 6, it is identified that the data of the argumentative structure consists only of two elements, namely the support and the claim. When compared in terms of quantity, Excerpt 6 only has one support and a more dominan claim, elaborated in subclaims. The claim 'So, former corruption convicts' is only supported by one data, namely 'I think we learn this and this is democracy, Sir.'

Furthermore, the claim is elaborated in the first subclaim, namely 'We will announce to the people that the people who do not want to vote for them, so be it. They should not give them votes to the former corruption convicts. What's important, Sir, is that the corruption case has been through the legal process. The convicts have served their time or when the law permits them to run for legislative election, it means that they are seen as capable and the people want them because of their other strengths, maybe the amount of money they corrupted was not much, maybe they got eh....maybe they....well, let's see if the petty criminals, you know, it's true that they are wrong for stealing chickens, but as long as they corrupted billions of money from the people, let's annihilate them from Indonesia.' Therefore, seen from the structure of the argument, Excerpt 6 is dominated by claim and subclaim.

Pragmatically, it can be said that the text above has a high degree of directness (32). This can be seen from the statements: 'the petty criminals'; 'let's annihilate them from Indonesia.' The relationship between the elements in Excerpt 6 can be illustrated as follows.

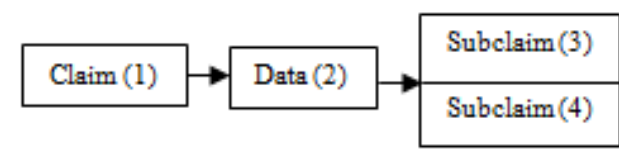

Chart 6. The structure of argument with C-D-Sc-Sc elements

\section{Excerpt 7:}

P: Kami tidak ingin banyak bicara. Kami sudah paham persoalan bangsa ini dan tahu apa yang harus kami lakukan. Kami tidak punya potongan diktator atau otoriter. Kami tidak punya rekam jejak melanggar HAM. Kami tidak punya rekam jejak melakukan kekerasan. Kami juga tidak punya rekam jejak masalah korupsi. J-A akan pertaruhkan jabatan dan reputasi dan akan kami gunakan semua kewenangan yang kami miliki untuk perbaikan bangsa ini.

\section{Translation:}

P: We do not want to say too much. We have understood the problems of the country and we know what we must do. We do not have a knack for being dictators or authoritarians. We do not have track records for human rights violation. We do not have track records for violence. We do not have track records for corruption. J-A will lay our titles and reputation and we will exercise our authority for the betterment of our country.

The argumentative text in Excerpt 7 has two elements, namely the claim and the support. Compared to Excerpt 6, the argument in Excerpt 7 provides a rich data. The claim of the above argument lies in the first sentence, which says 'We do not want to say too much.' The second sentence says 'We have understood the problems of the country and we know what we must do.' The sixth sentence says 'We do not have track records for corruption.' The seventh sentence 'J-A will lay our titles and reputation and we will exercise our authority for the betterment of our country,' is the subclaim, which confirms the claim at the beginning of the text. Despite the rich data, the argument in the excerpt lacks astuteness because it is not supported by the warrant as the link between the claim and the support.

The pragmatic analysis suggests that the argument in the above excerpt is firm and straightforward to convey the message. The firmness and straightforwardness show a high degree of directness in the communication context (6). The speaker's firmness appears in the use of the word 'kami' or the 'exclusive we' used repeatedly and consistently in each sentence in the text. The straightforwardness appears in the use of the expression: 'We do not have a knack for being dictators or authoritarians,'; We do not have track records for human rights violation,'; 'We do not have track records for violence,'; We do not have track records for corruption.' The real intention to convey by the presidential candidate is that he feels that he is suitable and more capable to run the country. He wants to convince the people that he is the candidate who is worthy to receive the mandate to lead the country because he does not have bad track records in the past (33).

The relationship between elements of the argument from Excerpt 7 is illustrated in the following pattern.

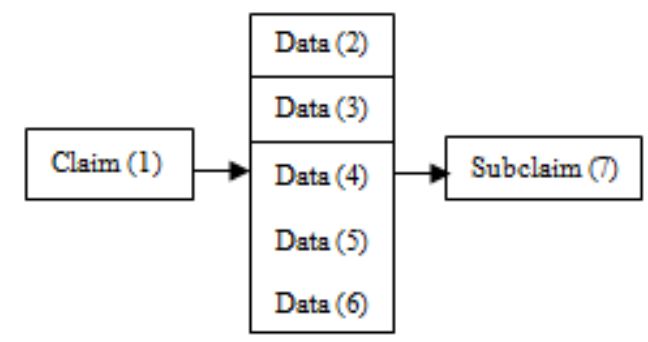

Chart 7. The structure of argument with C-D-D-D-D-DSc elements

Published By: Blue Eyes Intelligence Engineering 


\section{Excerpt 8:}

Mt: Saudara-saudara sekalian, kepastian hukum, penegakan hukum, institusi-institusi hukum terutama hakim, jaksa, dan polisi adalah prasyarat bagi suatu negara yang berhasil. Untuk itu kami apabila menerima mandat dari rakyat, hal ini yang akan kami perkuat, hal ini akan kami perbaiki, terutama kami akan bicara realistis untuk orang supaya kuat, supaya tidak korup, ini yang harus kita bangun penyelesaiannya. Jadi yang kami ingin adalah bicara penyelesaian akar masalah. Kita tidak mau cari kesalahan kecil-kecil ini, atau kita mengatakan ini salah, itu salah, siapa yang salah, tidak. Kami melihat ini persoalan bangsa, kami ingin menyelesaikan akar masalah karena itu kami bertekad, kami bertekad menaikkan tax ratio. Kami yakin negara ini sangat sangat kaya, tapi terjadi kebocorankebocoran kekayaan. Kekayaan kita mengalir ke luar negeri, ini bukan salah siapa saja, ini salah kita bersama sebagai bangsa, dan ini kesalahan elit yang membiarkan ini sudah puluhan tahun. Kita mau cari masalah jalan keluarnya, kita perbaiki, kita lipet gandaken gaji-gaji hakim, jaksa, dan polisi dan dengan demikian kita berharap akan ada lembaga hakim, lembaga polisi, lembaga jaksa yang tidak dapat dikorupsi. Mereka the incorruptible of our country, kita harus cari the best and brightest untuk di lembaga-lembaga itu supaya mereka menjadi pilar sehingga kita bebas dari korupsi.

\section{Translation:}

Mt: Ladies and gentlemen, legal certainty, law enforcement, law institutions, especially judges, prosecutors, and police force are the requirements of a country to succeed. For this purpose, if we were given mandate from the people, we will strengthen this. We will fix this, especially we will speak realistically for people to be strong, in order not to be corrupt; this is the solution we want to build. So, what we want is to speak of the solution to the root causes of the problems. We don't want to search for small errors, or saying 'this is wrong', 'that is wrong', 'who is at fault?', No! We want to see it as the country's problem, we want to solve the problems because we have vowed, we vow to increase the tax ratio. We are certain that this country is very rich, but there are leaks of the nation's wealth. The riches of the country flow outside the country, and it's not anyone's faults. It is the fault of the whole country. And this is the fault of the elite who have let this happen for decades. We want to find the way out. We will fix it. We will double the salary of the judges, prosecutors, and policemen so that we can hope for the institutions of judges, police, and prosecutors who are not corrupt. They will be the incorruptible of our country. We must find the best and the brightest for these institutions so they will be the pillars for anti-corruption movement.

Excerpt 8 has an argument which is dominated with the claim and the subclaim. The argument in the text excerpt consists of nine sentences, divided into one claim, seven subclaim, and one support. The claim says 'Ladies and gentlemen, legal certainty, law enforcement, law institutions, especially judges, prosecutors, and police force are the requirements of a country to succeed,' supported by 'The riches of the country flow outside the country, and it's not anyone's faults. It is the fault of the whole country. And this is the fault of the elite who have let this happen for decades.' The other sentences in this excerpt are subclaims. Therefore, it can be said that the argument in Excerpt 8 has a low degree of astuteness because it does not have the warrant which is the third major part to build a strong argument.

The substantial data presented in the previous excerpts show that the speaker pays attention to the marginalized people. The choice of words supports this and it can be seen in the following excerpt 'We want to find the way out. We will fix it. We will double the salary of the judges, prosecutors, and policemen so that we can hope for the institutions of judges, police, and prosecutors who are not corrupt.' The obvious intention to be seen and captured pragmatically from the statements spoken by the presidential candidates is that together we must seek solutions to the country's problems to find the way out of them. It is expected that in the future the society and the nation will prosper, the lawa supremacy is maintained, so that the dream to have a harmonious, peaceful, secure, and prosperous society will come true (34). The argument pattern from Excerpt 8 is illustrated in the following chart.

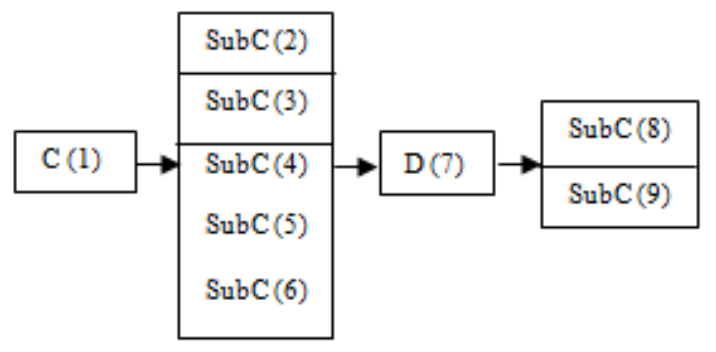

Chart 8. The structure of argument with C-So-Sc-So-Sc-So-D-Sc-Scelements

\section{CONCLUSION}

Based on the above analysis, it can be concluded that the structure of an argument presented by the presidential candidates and their running mates in the first-round presidential debate is clear and simple. Data shows that most of the arguments start from the positional statement (the claim) which is followed by supports and warrant. Some analyzed data also shows that the presidential candidates start their arguments by presenting data first before following it with positional statement (the claim) and the warrant. The sub-claim also appears in some data.

The sub-claim is raised by the presidential candidates in the debate when they feel that the claim they have made needs more elaboration to gain stronger effect. Most of the data shows that the major parts of Toulmin's argument, i.e. the claim, the support, and the warrant, are fulfilled in the presidential candidates' arguments.

Furthermore, from the critical pragmatic perspective, it can be confirmed that the presidential candidates and their running mates have great concern and care for the marginalized, disadavantaged, and neglected people in the society and nationhood. The great concern is evident in the choice of words in their speech. Their dictions indicate that 
each of the president candidates take sides with the economically, socially, politically disadvantaged people.

A conclusion section is not required. Although a conclusion may review the main points of the paper, do not replicate the abstract as the conclusion. A conclusion might elaborate on the importance of the work or suggest applications and extensions.

\section{ACKNOWLEDGEMENT}

This research is supported by DRPM, Ministry of Research, Technology, and Higher Education, Republic of Indonesia. The writers thank the continual supports given for more than six years.

\section{REFERENCES}

1. Ilie C. Parliamentary debates. In: The Routledge Handbook of Language and Politics. 2017.

2. Peng MW, Pleggenkuhle-Miles EG. Current debates in global strategy. Int J Manag Rev. 2009;

3. van Eemeren FH, Garssen B, Krabbe ECW, Henkemans AFS, Verheij B, Wagemans JHM. Toulmin's Model of Argumentation. In: Handbook of Argumentation Theory. 2013.

4. Kneuper CW. Teaching Argument: An Introduction to the Toulmin Model. Coll Compos Commun. 1978;

5. Gu Y. Doing pragmatics. J Pragmat. 1998;

6. Science L, Company $\mathrm{P}$, Long $\mathrm{MH}$, Canagarajah $\mathrm{S}$, Peterson RA, Nagel J, et al. An Introduction to Discourse Analysis: Theory and Method. J Pragmat. 2017;

7. Rahardi RK. Personal and Communal Assumptions to Determine Pragmatic Meanings of Phatic Functions. Ling Cult [Internet]. 2016;10(10(2)):95-8. Available from: http://dx.doi.org/10.21512/lc.v10i2.897

8. Midtgarden T. Critical Pragmatism. Eur J Soc Theory. 2012;

9. Rahardi RK. Pragmatic Phenomena Constellation in Specific Culture Dimension Language Study. Int J Humanit Stud. 2017;1(1):84-92.

10. Gunter Senft. Understanding Pragmatics. 1st ed. New York: Routledge; 2014. 233 p.

11. Mao L. Pragmatics: An introduction. J Pragmat. 2003;

12. Ile C. Understanding pragmatics. J Pragmat. 2001;

13. Leech G. Principles of Pragmatics. Journal of Linguistics. 1983.

14. Rahardi RK. Pragmatik: Kefatisan berbahasa sebagai fenomena pragmatik baru dalam perspektif sosiokultural dan situasional. 1st ed. Jakarta: Erlangga; 2018.

15. Rahardi RK. Menemukan Hakikat Konteks Pragmatik. Pros Semin PRASASTI. 2015;

16. Huang Q. Interlanguage Pragmatics Theory and Its Implications for Foreign Language. J Lang Teach Res. 2010;

17. Clark HH. Pragmatics of Language Performance. In: The Handbook of Pragmatics. 2008.

18. Meyer CF, Halliday MAK, Hasan R. Language, Context, and Text: Aspects of Language in a Social-Semiotic Perspective. TESOL Q. 2006;

19. Allan K. The pragmatics of connotation. J Pragmat. 2007;

20. Allan K, Jaszczolt K. The Cambridge handbook of pragmatics. Cambridge University Press. 2012.

21. Scollon R, Scollon SW. Intercultural Communication. A discurse Approach. SocioLinguistics. 2001.

22. van Eemeren FH, Garssen B, Krabbe ECW, Snoeck Henkemans AF, Verheij B, Wagemans JHM. Argumentation Theory Argumentation theory. In: Handbook of Argumentation Theory. 2013.
23. Goldberg AE. Pragmatics and Argument Structure. In: The Handbook of Pragmatics. 2008.

24. Yuliana Setyaningsih. Metakognisi sebagai Keterampilan Melatih Siswa Berpikir Kritis dalam Pembelajaran Bahasa. In: Yuliana Setyaningsih dan R. Kunjana Rahardi, editor. Prosiding Seminar Nasional PBSI, FKIP, Universitas Sanata Dharma. Yogyakarta: Universitas Sanata Dharma; 2013. p. 166.

25. Mahsun M. Metode Penelitian Bahasa. Jakarta PT Raja Grafindo Persada. 2005;

26. Breeze R. Critical discourse analysis and its critics. Pragmatics. 2011;

27. Agar M. Language, power and ideology: Studies in political discourse. Journal of Pragmatics. 1991.

28. Bhatia A. The discourses of terrorism. J Pragmat. 2009;

29. Szasz TS. Language and Humanism. Humanist. 1974;

30. Steffensen SV, Fill A. Ecolinguistics: The state of the art and future horizons. Lang Sci. 2014;

31. Schilling J. On the Pragmatics of Qualitative Assessment. Eur J Psychol Assess. 2006;

32. Flores-Salgado E, Castineira-Benitez TA. The use of politeness in WhatsApp discourse and move 'requests.' J Pragmat. 2018;

33. Edelman M, Bourdieu P, Thompson JB, Raymond G Adamson M. Language and Symbolic Power. Contemp Sociol. 1992;

34. Limberg $H$. Principles for pragmatics teaching: Apologies in the EFL classroom. ELT J. 2015;

\section{AUTHOR'S PROFILE}

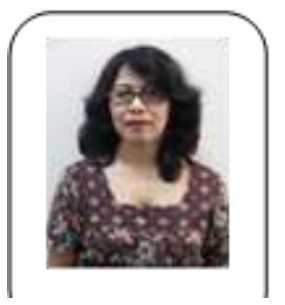

Dr. Yuliana Setyaningsih, M.Pd., wa born in Surakarta on October 1, 1963. She serves as the Lecturer of Indonesia Language and Literature Education Study Program, Faculty of Teachers Training and Education, Sanata Dharma University, Yogyakarta. She served as the Head Department of the Indonesian and Literature Study Program for two periods starting from 2009 until 2017. She graduated from the Doctorate Program of Indonesian Education University in Indonesian Education Teaching Study Program in January 2007. The textbooks during her doctorate tenure are: Fonologi dalam Bahasa Indonesia (Universitas Sanata Dharma Press, Yogyakarta, 2014), Pragmatik: Fenomena Ketidaksantunan Berbahasa (Erlangga Publisher Jakarta, 2016) as the cowriter, Menulis Artikel Jurnal: Panduan Mencipta Karya Ilmiah Bermutu dengan Pengembangan Argumentasi Berperspektif Stephen Toulmin (Amara Books Publisher Yogyakarta, 2018) Model Peningkatan Kualitas Argumen Paragraf-paragraf Argumentatif Bagian Pembahasan Artikel Jurnal Terakreditasi, Amara Books Publisher Yogyakarta, 2017), Kefatisan Berbahasa: Studi fenomena kebahasaan dalam perspektif sosiokultural dan situasional, Amara Books Publisher Yogyakarta, 2017) as the co-writer She did her thoughts in Indonesian Language Teaching, Evaluation, Curriculum Development, and Critical Writing based on Toulmin's Model and they have been exposed in various national and international forums documented in various proceedings and journal articles.

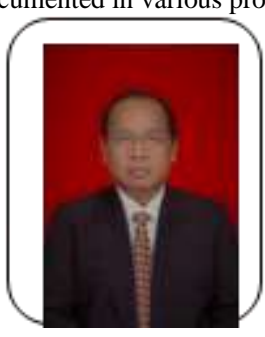

Dr. R. Kunjana Rahardi, M.Hum., was born in Yogyakarta on October 13, 1966. He serves as the Head of Master Program in the Indonesian Language and Literature Education, Faculty of Teachers Training and Education, Sanata Dharma University, Yogyakarta. He graduated from the Doctorate Program of Gadjah Mada University in linguistics in 1999. The linguistic textbooks during his doctorate tenure are: Pragmatik: Kesantunan Imperatif dalam Bahasa Indonesia (Erlangga Publisher Jakarta, 2006), Asyik Berbahasa Jurnalistik: Kalimat Jurnalistik dan Temali Masalahnya (Santusta Publisher 
International Conference on Recents Advancements in Engineering and Technology (ICRAET-18) |15th and 16th March 2019|Siddhartha Institute of Technology \& Sciences, Telangana, India.

Yogyakarta, 2006), Paragraf Jurnalistik: Menyusun Alinea Bernilai Rasa dalam Bahasa Laras Media (Santusta Publisher Yogyakarta, 2006), Dasardasar Bahasa Penyuntingan Media [Gramata Publisher Jakarta, 2009], Penyuntingan Bahasa Indonesia untuk Karang-mengarang [Erlangga Publisher Jakarta, 2009], Menulis Artikel Opini dan Kolom di Media Massa (Erlangga Publisher Jakarta, 2012), Fonologi dalam Bahasa Indonesia (Universitas Sanata Dharma Press, Yogyakarta, 2014), Sosiopragmatik [Erlangga Publisher Jakarta, 2009 Kajian Sosiolinguistik Kode dan Alih Kode (revised edition) (Ghalia Publisher Indonesia, Jakarta, 2010, 2015), Bahasa Indonesia Perguruan Tinggi: Mata Kuliah Pengembangan Kepribadian (Erlangga Publisher Jakarta, 2010), Bahasa Jurnalistik: Pedoman Kebahasaan untuk Mahasiswa, Jurnalis, dan Umum (Ghalia Publisher Indonesia, Jakarta, 2010; 2015), Pragmatik: Fenomena Ketidaksantunan Berbahasa (Erlangga Publisher Jakarta, 2016), Pragmatik: Fenomena Kefatisan Berbahasa dalam Perspektif Sosio-kultural dan Situasional (Erlangga, Jakarta 2018). He did his thoughts in pragmatics and its interesting sides have been exposed in various nasional and international forums documented in various proceedings and journal articles. He did the research consecutively for five years (in 2013 until 2015 and in 2016 until 2018) on Impoliteness in Indonesian Language and on Phatic Communion in Indonesian Language with the grants given by Directorate of Research and Community Service, Ministry of Research, Technology and Higher Education, Republic of Indonesia. 